\title{
Comparison of nitrifier activity versus growth in the Scheldt estuary - a turbid, tidal estuary in northern Europe
}

\author{
Maria G. I. Andersson ${ }^{1, *}$, Natacha Brion ${ }^{2}$, Jack J. Middelburg ${ }^{1}$ \\ ${ }^{1}$ Netherlands Institute of Ecology (NIOO-KNAW), Centre for Estuarine and Marine Ecology, \\ PO Box 140, 4400 AC Yerseke, The Netherlands \\ ${ }^{2}$ Labo voor Analytische en Milieu Chemie, Vrije Universiteit Brussel, Pleinlaan 2, 1050 Brussels, Belgium
}

\begin{abstract}
Nitrifier activity and growth were measured in the Scheldt estuary over a salinity gradient. Measurements were made during all 4 seasons using ${ }^{15} \mathrm{~N}$ enriched ammonium and ${ }^{14} \mathrm{C}$ labeled carbon incorporation. Established conversion ratios are often used to convert the growth of nitrifiers (measured as the incorporation of carbon) to nitrifying activity (i.e. oxidation of ammonium to nitrate). Our study demonstrated that the conversion of growth rates to nitrifying activity induces uncertainty because activity and growth of nitrifiers may be uncoupled. The C: $\mathrm{N}$ conversion ratio appears to be oxygen and temperature dependent. We advocate the use of ${ }^{15} \mathrm{~N}$ stable isotope techniques to study nitrification: this technique measures the actual activity of nitrifiers without the disadvantages involved in using inhibitors, and thus allows light inhibition to be measured.
\end{abstract}

KEY WORDS: Nitrification $\cdot$ Nitrifier activity $\cdot$ Nitrifier growth $\cdot{ }^{15} \mathrm{~N}$ stable isotopes $\cdot{ }^{14} \mathrm{C}$ bicarbonate Resale or republication not permitted without written consent of the publisher

\section{INTRODUCTION}

Nitrification, the microbial oxidation of ammonium $\left(\mathrm{NH}_{4}{ }^{+}\right)$, is one of the key nitrogen transformation processes. It is performed under oxic conditions by 2 groups of bacteria, one group that oxidizes ammonium to nitrite $\left(\mathrm{NO}_{2}{ }^{-}\right)$and a second group that further oxidizes nitrite to nitrate $\left(\mathrm{NO}_{3}{ }^{-}\right)$. Nitrification links organic matter mineralization (ammonification) and nitrogen removal through denitrification (conversion of nitrate to nitrogen gas). Nitrifying bacteria are chemolithoautotrophic organisms which use energy from the oxidation of $\mathrm{NH}_{4}{ }^{+}$or $\mathrm{NO}_{2}{ }^{-}$to fix inorganic carbon in their biomass. Accordingly, nitrification links the flows of nitrogen with those of oxygen and carbon. In ammonium-rich systems, nitrification may make significant contributions to, or even dominate, total oxygen consumption and carbon fixation. Nitrifiers were responsible for up to $60 \%$ of the total $\mathrm{O}_{2}$ consumption in the Seine estuary, France (Garnier et al. 2001). Nitrification is the most important carbon fixation process in the upper part of the Scheldt estuary (Soetaert \& Herman 1995), where it ac- counts for 12 to $78 \%$ of oxygen consumption (Gazeau et al. 2005). One by-product formed during nitrification is nitrous oxide gas $\left(\mathrm{N}_{2} \mathrm{O}\right)$, which contributes to global warming and ozone depletion. de Wilde \& de Bie (2000) showed that a major portion of $\mathrm{N}_{2} \mathrm{O}$ production in the Scheldt estuary results from nitrification, and that almost all of it is lost to the atmosphere within the estuary and is not transported out to sea.

In recognition of the pivotal role of nitrification in estuarine biogeochemistry, research has been initiated to identify the organisms and governing factors of this process so that it may be accurately quantified (Bollmann \& Laanbroek 2002, de Bie et al. 2002, Caffrey et al. 2003). One of the most common methods to measure nitrification rates is the $\mathrm{N}$-serve sensitive ${ }^{14} \mathrm{C}$-bicarbonate incorporation technique (Somville 1978, Brion \& Billen 1998), henceforth referred to as the ${ }^{14} \mathrm{C}$ method. It is based on the incorporation of inorganic carbon by growing nitrifiers. Nitrification rates measured with the ${ }^{14} \mathrm{C}$ method are expressed as the amount of carbon incorporated over time. However, many researchers are interested in nitrogen transfor- 
mations (rather than nitrifier growth) and use a conversion factor to express these carbon incorporation rates into nitrogen oxidation rates. This approach requires (1) a tight coupling between nitrifier activity $\left(\mathrm{NH}_{4}{ }^{+}\right.$oxidation to $\mathrm{NO}_{2}{ }^{-}$or $\mathrm{NO}_{3}{ }^{-}$) and growth (carbon incorporation), and (2) a fixed stoichiometry between the quantity of nitrogen transformed and carbon fixed. Although these 2 requirements are essential for the conversion of $\mathrm{C}$ incorporation rates into $\mathrm{N}$ oxidation rates, their validity has not been tested thoroughly in natural conditions.

Nitrifying bacteria are relatively slow growing (growth rates between 0.04 and $0.06 \mathrm{~h}^{-1}$ (Helder \& de Vries 1983), implying that nitrifying communities need time to adapt to environmental changes. Organisms in estuarine systems are submitted to variable biogeochemical conditions. Seasonal factors like temperature, nutrient availability and oxygen concentration can affect nitrifier activity and growth (Carlucci \& McNally 1969, Goreau et al. 1980, Berounsky \& Nixon 1993, Bodelier et al. 1996, Bollmann et al. 2002). Estuarine nitrifier populations are subject to large environmental variations because of tides and strong salinity gradients across estuaries. Different populations of ammonium oxidizing bacteria occur at estuarine sites with different salinities (de Bie et al. 2001, Bollmann \& Laanbroek 2002). In turbid estuaries, nitrifying bacteria are attached to suspended particulate matter in a manner similar to that in a 'fluidized bed reactor' (Owens 1986, Brion \& Billen 2000). Particle-attached nitrifiers experience a longer residence time in the estuary, which allows them to develop their population (Brion et al. 2000). However, these particles with associated nitrifiers are subject to repeated cycles of settling and resuspension. Given these multiple causes of environmental variability, one might question whether nitrifier growth (as measured with the ${ }^{14} \mathrm{C}$ method) and activity are coupled. The main aim of the present study was to assess whether nitrifier activity and growth are so tightly coupled that nitrogen oxidation can be estimated from carbon incorporation in combination with conversion factors. In parallel with the ${ }^{14} \mathrm{C}$ method, nitrification rates in the Scheldt estuary were measured with a stable isotope technique where ${ }^{15} \mathrm{~N}$ labeled $\mathrm{NH}_{4}{ }^{+}$ was added and the appearance of ${ }^{15} \mathrm{~N}_{\text {in }} \mathrm{NO}_{3}{ }^{-}$after incubation was measured.

\section{MATERIALS AND METHODS}

Study area. The Scheldt estuary is located in the southwest of the Netherlands and Belgium. The estuary is fed by the Scheldt river which originates in northern France (St. Quentin) and flows into the North Sea near Vlissingen (Netherlands). The Scheldt estuary constitutes a dynamic environment: it is turbid and well mixed, with a water residence time of about 2 mo (Heip 1988). The tidal amplitude is high, ranging from $3.8 \mathrm{~m}$ in the western to $5.2 \mathrm{~m}$ in the eastern part, and the estuary is about $100 \mathrm{~km}$ long covering an area of $\sim 300 \mathrm{~km}^{2}$. The total catchment area of the Scheldt river is $22000 \mathrm{~km}^{2}$, contains several large industrial areas, and supports a population of approximately 10 million (Soetaert et al. 2005). Compared to other tidal estuaries, the maximum turbidity values in the Scheldt are low and the zone of maximum turbidity less pronounced. The river and its tributaries are a major drain for industrial and domestic waste discharges, which are not all treated in waste water treatment plants. Water quality is poor in the greater part of the river and the eastern part of the estuary (Baeyens et al. 1998). Until the mid 1970s discharges caused an increase in nutrient levels, but after the end of the 1970s nutrient loading decreased and the oxic conditions of the Scheldt estuary improved (Soetaert et al. 2005). In the early 1970s denitrification occurred in the water column, but since 1980 water column denitrification has been reduced and a nitrification front has progressed toward the freshwater section. Water column denitrification has not occurred since 1990, and since 2000 most nitrification has occurred in the upstream region (Soetaert et al. 2005). Nevertheless, nitrification is the most pervasive process of the nitrogen cycle in the Scheldt estuary.

Sampling. During 2003, 4 cruises were conducted with RV 'Luctor' in January, April, July, and October, 1 in each of 4 seasons. Five stations were sampled during every cruise. The stations were of fixed salinity but their exact location varied depending on tide and discharge. The salinities of the 5 stations were $0,2,8$, 18 and 28, and these numbers are used as station names from this point onwards. Stn 0 was located close to Dendermonde, Belgium, $122 \mathrm{~km}$ from the mouth of the estuary, whereas Stn 28 was located at the mouth of the estuary, close to Vlissingen, the Netherlands (Fig. 1). Since the stations were situated along a salinity gradient, nutrient and oxygen concentrations and bacterial communities differed among the 5 . Water was sampled in 201 Niskin bottles from approximately $2 \mathrm{~m}$ depth and subsampled immediately after retrieval of each bottle.

Concentration measurements. Samples were taken from 17 fixed monitoring stations along a transect through a salinity gradient that ranged from 0 to marine. The water was filtered through preweighed, precombusted Whatman GF/F filters $(47 \mathrm{~mm})$, stored frozen, and then analyzed for ammonium, nitrate and nitrite using automated colorimetric techniques. The filters were weighed and analyzed for concentrations of suspended particulate matter (SPM) and particulate organic carbon and nitrogen using a Carlo Erba NA 
1500 elemental analyzer (Nieuwenhuize et al. 1994). Salinity, temperature and oxygen were measured at all 17 stations.

Nitrification measurements. ${ }^{15} \mathbf{N}$ method: Water samples were spiked with $98 \%{ }^{15} \mathrm{~N}$-labeled $\mathrm{NH}_{4}{ }^{+}$, at levels that approximated $2.5 \%$ of ambient $\mathrm{NH}_{4}{ }^{+}$concentration. Samples were incubated at in situ temperatures in dark bottles in a tank with running estuarine water. Incubations were terminated after 3, 6, 9, 12 and $24 \mathrm{~h}$ by filtration through precombusted Whatman $\mathrm{GF} / \mathrm{F}$ filters $(20 \mathrm{~mm})$. MgO $\left(3 \mathrm{~g} \mathrm{l}^{-1}\right)$ and (depending on salinity of the sample) $\mathrm{NaCl}$ were added to the water immediately after filtration, to a final salinity of 35 . Measurements of $\delta^{15} \mathrm{NH}_{4}{ }^{+}$and $\delta^{15} \mathrm{NO}_{3}{ }^{-}$were based on the diffusion method of Sigman et al. (1997) and Holmes et al. (1998), as modified by Middelburg \& Nieuwenhuize (2001) in order to extract the $\mathrm{NH}_{4}{ }^{+}$from the water. The $\mathrm{NH}_{4}{ }^{+}$dissolved in water samples was converted to ammonia gas $\left(\mathrm{NH}_{3}\right)$ under alkaline conditions. The $\mathrm{NH}_{3}$ was then trapped as ammonium sulfate on an acidified precombusted Whatman GF/D $10 \mathrm{~mm}$ filter, sandwiched between two $2.5 \mathrm{~cm}, 10 \mu \mathrm{m}$ pore size Teflon membranes. After trapping $\mathrm{NH}_{4}{ }^{+}$in the sample, Devarda's alloy was added to convert all $\mathrm{NO}_{3}{ }^{-}$to $\mathrm{NH}_{4}{ }^{+}$, which was then extracted as described above. Since all the original $\mathrm{NH}_{4}{ }^{+}$was removed during the first step, $\mathrm{NH}_{4}{ }^{+}$trapped on the second filter was completely derived from $\mathrm{NO}_{3}{ }^{-}$. The ${ }^{15} \mathrm{~N}$ content of the GF/D filters was determined using a Fisons NA 1500 elemental analyzer coupled to a Finnigan Delta S masspectrometer via a Conflo II interface. During incubation, the ${ }^{15} \mathrm{~N}$ label added as $\mathrm{NH}_{4}{ }^{+}$was oxidized through nitrification and appeared in $\mathrm{NO}_{3}{ }^{-}$(see Fig. 3). Control experiments (to which the nitrification inhibitors N-serve and chlo-

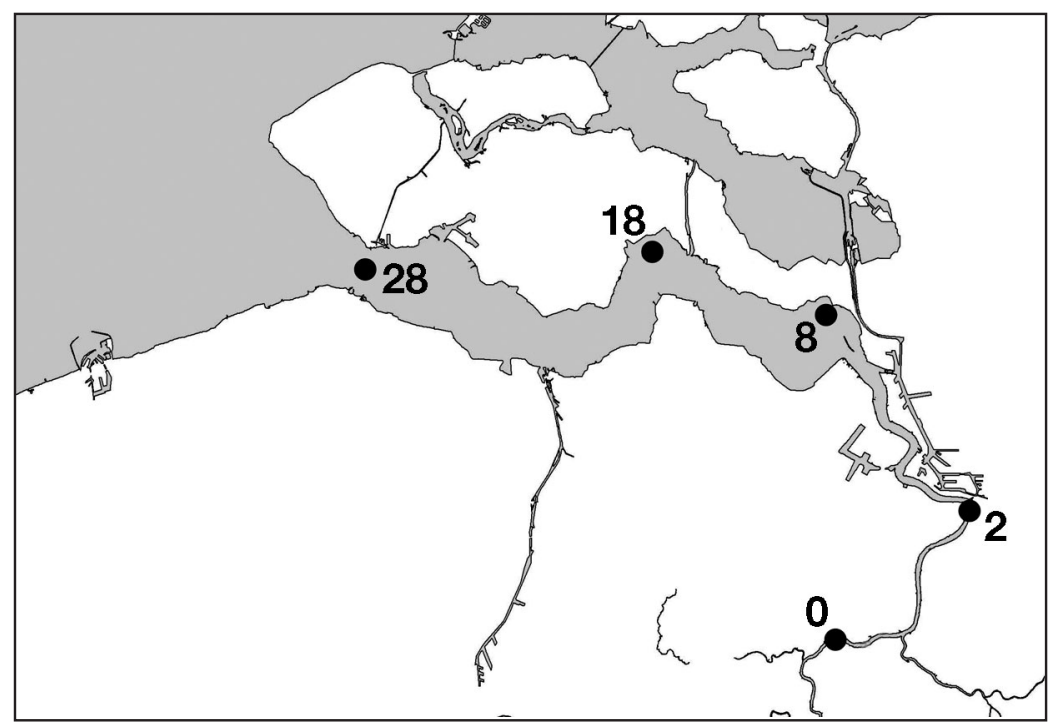

Fig. 1. Scheldt estuary. Numbers indicate salinity and approximate location of stations rate [see below] were added) showed no transfer of ${ }^{15} \mathrm{~N}$ from the $\mathrm{NH}_{4}{ }^{+}$to $\mathrm{NO}_{3}{ }^{-}$pool during $24 \mathrm{~h}$.

When the increase of ${ }^{15} \mathrm{~N}$ in $\mathrm{NO}_{3}{ }^{-}$was linear (see Fig. 3a) a linear regression was fitted, but in some cases a curve gave a better fit (see Fig. 3b, 'Results'):

$$
Y=a_{0}-a_{1} \mathrm{e}^{-k t}
$$

Results from these regressions were used to calculate nitrification rates $\left(R_{N}\right)$ using the following equation (Dugdale \& Goering 1967):

$$
R_{N}=\frac{b}{\left(\alpha_{\mathrm{NH}_{4}{ }^{+}}-\alpha_{n}\right)}\left[\mathrm{NO}_{3}^{-}\right]
$$

where $b$ is the slope obtained from the linear regression or the initial slope obtained with the fitted curve (atom\% ${ }^{15} \mathrm{~N} \mathrm{~h}^{-1}$ ), $\alpha_{\mathrm{NH}_{4^{+}}}$is the initial ${ }^{15} \mathrm{~N}$ content in $\mathrm{NH}_{4}{ }^{+}$after addition of ${ }^{15} \mathrm{~N}, \alpha_{n}$ is the natural abundance of ${ }^{15} \mathrm{~N}$ in $\mathrm{NH}_{4}{ }^{+}$, and $\left[\mathrm{NO}_{3}{ }^{-}\right]$is the average in situ concentration of $\mathrm{NO}_{3}{ }^{-}$during incubation, which was measured on the filtered water sample as described above. The estimated errors of $R_{N}$ were obtained from the variance/ covariance matrix of the fitted parameters and error propagation. Eq. (2) does not take other processes such as uptake or regeneration into account. Uptake of $\mathrm{NH}_{4}{ }^{+}$should not affect the fraction of ${ }^{15} \mathrm{~N}$ in $\mathrm{NH}_{4}{ }^{+}$and consequently not influence the nitrification rate. If a high uptake of $\mathrm{NO}_{3}{ }^{-}$occurred, the calculated nitrification rates would be underestimated. Parallel measurements of the uptake of $\mathrm{NH}_{4}{ }^{+}$and $\mathrm{NO}_{3}{ }^{-}$demonstrated that $\mathrm{NH}_{4}{ }^{+}$is taken up to a much larger extent than $\mathrm{NO}_{3}{ }^{-}$. Regeneration of $\mathrm{NH}_{4}{ }^{+}$would dilute the ${ }^{15} \mathrm{~N}$ content of $\mathrm{NH}_{4}{ }^{+}$ and cause nitrification rates to be underestimated at high regeneration rates.

${ }^{14}$ C method: Carbon incorporation by autotrophic nitrifiers was measured with the inhibitor based ${ }^{14} \mathrm{C}$-bicarbonate incorporation technique as described by Brion \& Billen (1998). Water samples, taken from the same Niskin bottle as the samples used for the ${ }^{15} \mathrm{~N}$ method, were spiked with ${ }^{14} \mathrm{C}$-bicarbonate (50 $\mathrm{mCi} \mathrm{mmol}^{-1}$, Amersham) to a final concentration of $5 \mu \mathrm{mol} \mathrm{l}^{-1}$ and incubated in dark bottles in the tank mentioned above. Carbon incorporation was measured at 3 time intervals over a 9 to $24 \mathrm{~h}$ period. Incorporation due to nitrifier growth was determined using the difference between the amount of $\mathrm{H}^{14} \mathrm{CO}_{3}{ }^{-}$incorporated in samples with and without nitrificationspecific inhibitors. N-serve (2-chloro-6trichloromethyl pyridine; $5 \mathrm{mg} \mathrm{ml}^{-1}$ ) and sodium chlorate $\left(\mathrm{NaClO}_{3} ; 10 \mathrm{mM}\right)$ 


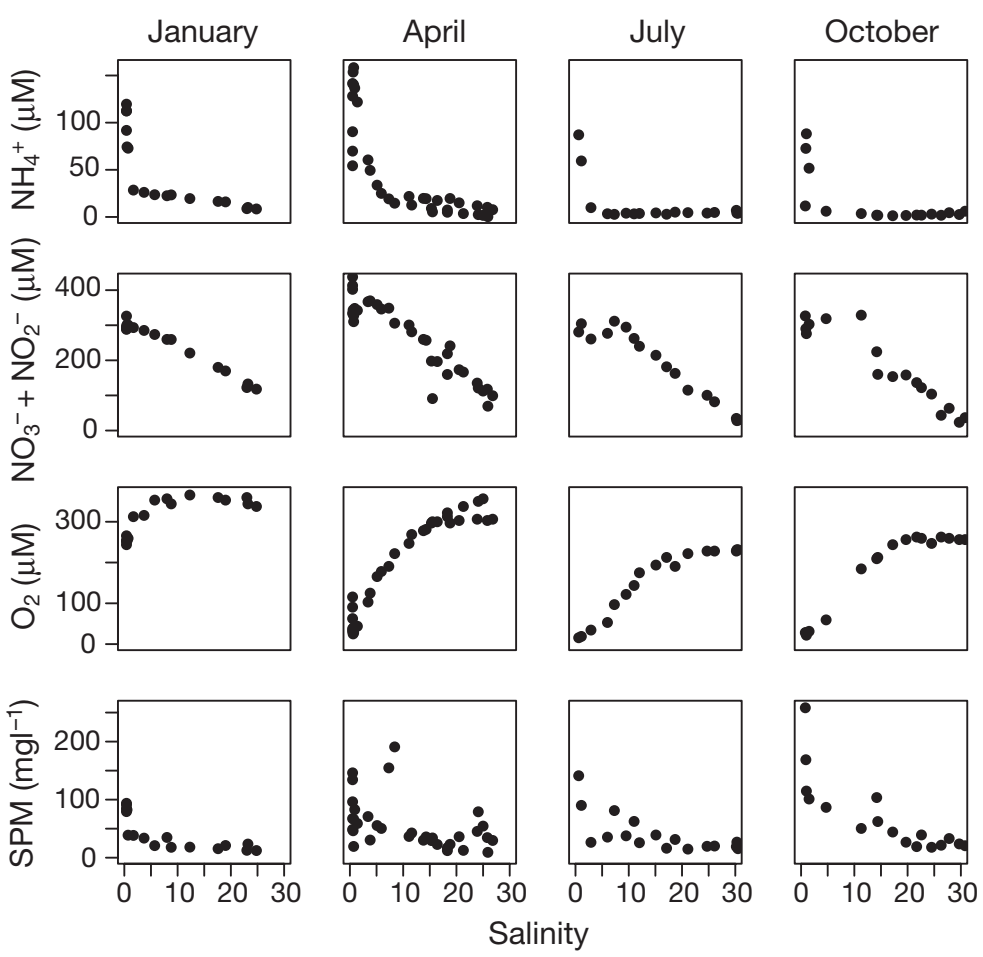

Fig. 2. Concentrations of $\mathrm{NH}_{4}{ }^{+}, \mathrm{NO}_{3}^{-}+\mathrm{NO}_{2}^{-}, \mathrm{O}_{2}$ and suspended particulate matter (SPM) in the pelagic zone of the Scheldt estuary during 2003

were used to inhibit the ammonium and nitrite oxidation, respectively. Nitrification rates (expressed in $\mathrm{nM} \mathrm{C}{ }^{-1}$ ) were calculated as the slope difference of linear regression lines of $\mathrm{C}$ incorporation versus time between samples with and without the inhibitor.

Pilot study. Prior to initiation of the field experiments, a pilot experiment was conducted. In November 2002, water from a fresh water station in the Scheldt estuary was sampled and nitrification rates were measured using the ${ }^{15} \mathrm{~N}$ and ${ }^{14} \mathrm{C}$ method (as described above) in a laboratory where more extensive sampling was possible than during a cruise. Moreover, incubations with the ${ }^{15} \mathrm{~N}$ method were performed under dark and light (approximately $200 \mu \mathrm{mol}$ photons $\mathrm{m}^{-2} \mathrm{~s}^{-1}$ ) conditions to assess the light dependence of nitrification.

\section{RESULTS}

\section{Concentration measurements}

Concentrations of $\mathrm{NH}_{4}{ }^{+}$and $\mathrm{NO}_{3}{ }^{-}+\mathrm{NO}_{2}{ }^{-}$showed a similar pattern in all seasons (Fig. 2). $\mathrm{NH}_{4}{ }^{+}$concentrations were highest in the fresh water section of the estuary $(\leq 150 \mu \mathrm{M})$ and decreased with increasing salinity. The decrease was faster during July and October. $\mathrm{NO}_{3}{ }^{-}+\mathrm{NO}_{2}{ }^{-}$concentrations in the fresh water sec- tion were around $300 \mu \mathrm{M}$, either increased or were uniform until a salinity of $\sim 10$, and from there decreased throughout the estuary. The decrease of $\mathrm{NH}_{4}{ }^{+}$and increase of $\mathrm{NO}_{3}{ }^{-}$in the upper estuary reflected intensive nitrification. The $\mathrm{O}_{2}$ concentration varied among seasons and also along the estuary transect. Oxygen concentrations were generally low in the upper part of the estuary, even hypoxic during July and October. Oxygen concentrations increased toward the mouth of the estuary and reached saturation levels and even supersaturation $(415 \mu \mathrm{M})$ in April. The SPM varied from $250 \mathrm{mg} \mathrm{l}^{-1}$ in fresh water in October to $10 \mathrm{mg} \mathrm{l}^{-1}$ in marine water in January. Water temperature varied with season and was recorded at 4, 10, 20 and $14^{\circ} \mathrm{C}$ in January, April, July and October, respectively.

\section{Nitrification rates}

In most samples, the ${ }^{15} \mathrm{~N}$ in $\mathrm{NO}_{3}{ }^{-}$showed a linear increase with time (Fig. 3b), but for some (Fig. 3a) the increase was non-linear. Non linearity could be explained by substrate limitation, as shown in the comparison of $\mathrm{NO}_{3}{ }^{-}$production at Stns 0 and 2. At Stn 2 the $\mathrm{NH}_{4}{ }^{+}$concentration at the start of incubation was $14 \mu \mathrm{M}$ and the nitrification rate was $124 \mathrm{nM} \mathrm{h}^{-1}$, which meant that only $16 \%$ of the initial $\mathrm{NH}_{4}{ }^{+}$was consumed during the $24 \mathrm{~h}$ incubation. At Stn 0 the initial $\mathrm{NH}_{4}{ }^{+}$concentration was $4 \mu \mathrm{M}$ and the nitrification rate was
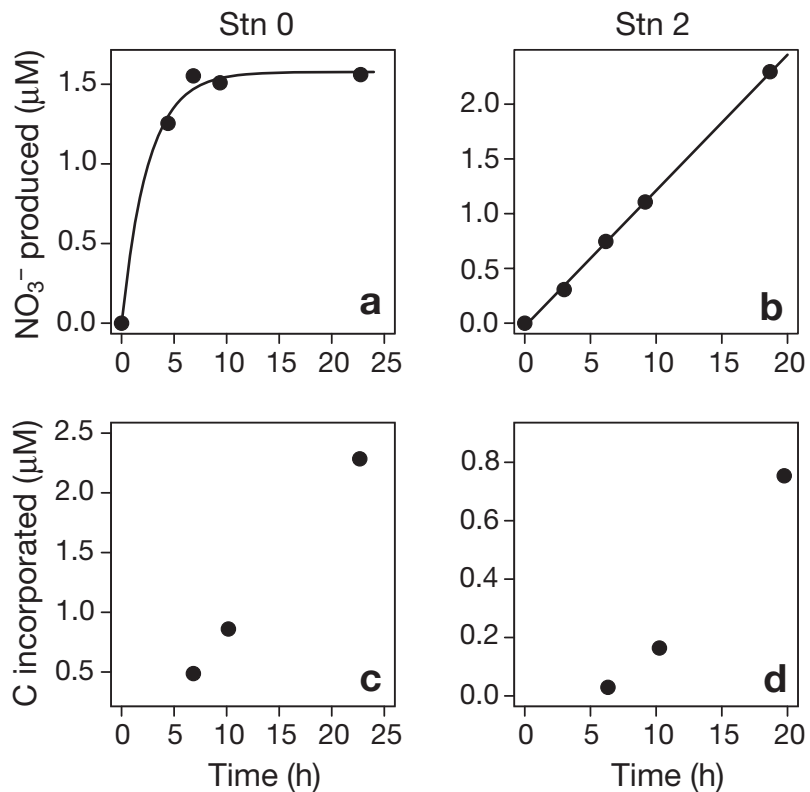

Fig. 3. $(\mathrm{a}, \mathrm{b}) \mathrm{NO}_{3}{ }^{-}$produced and $(\mathrm{c}, \mathrm{d})$ carbon incorporated at Stns 0 and 2 in July 2003 

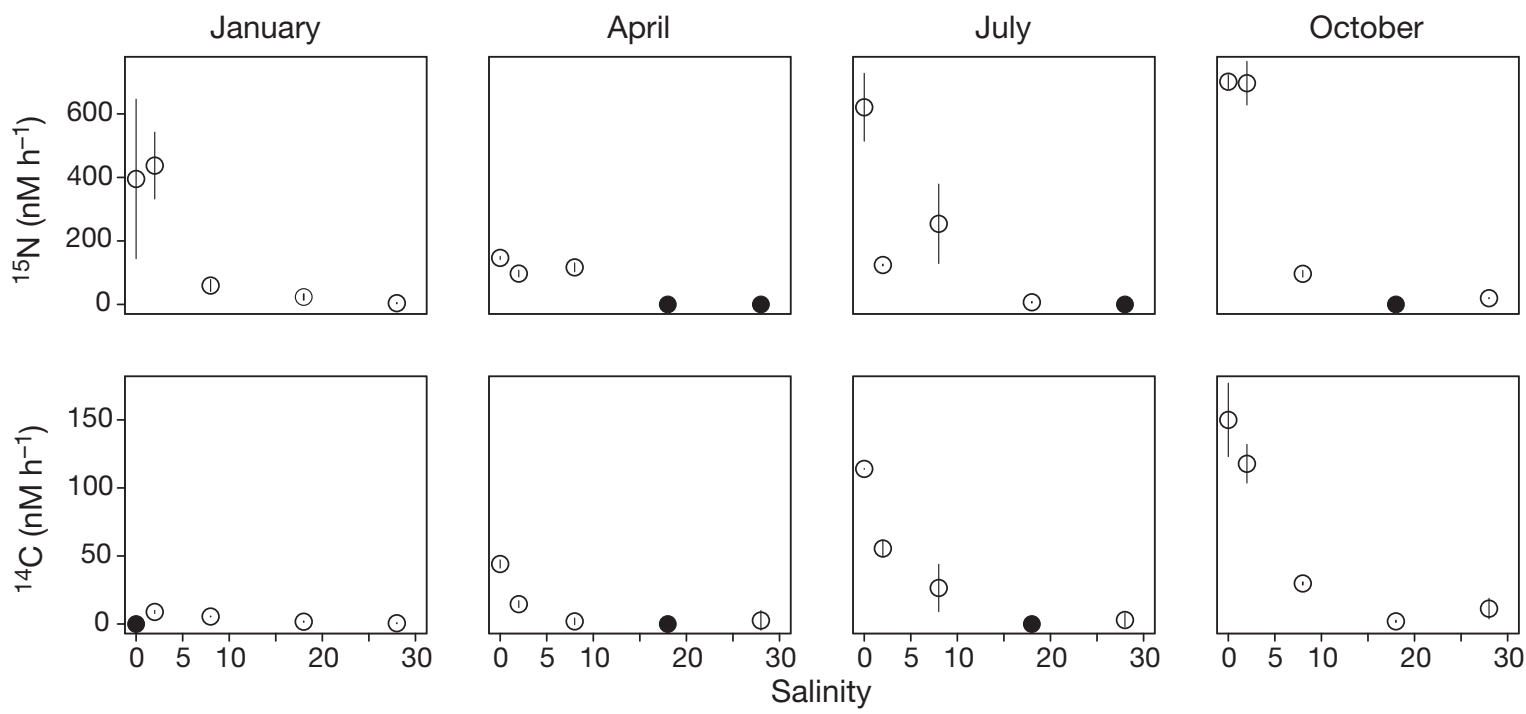

Fig. 4. Nitrification rates measured with (top row) ${ }^{15} \mathrm{~N}$ method or (bottom row) ${ }^{14} \mathrm{C}$ method during 4 seasons over a salinity gradient. For details of the 2 methods, see 'Materials and methods'. (•) Not detectable; errors are SE calculated from fitted parameters

$621 \mathrm{nM} \mathrm{h}^{-1}$. At this rate, the initial stock of $\mathrm{NH}_{4}{ }^{+}$was consumed within $6 \mathrm{~h}$ of the incubation. Regeneration of $\mathrm{NH}_{4}{ }^{+}$during incubation may also have contributed to the non-linear increase of ${ }^{15} \mathrm{~N}$ in $\mathrm{NO}_{3}^{-}$: in this case, ${ }^{15} \mathrm{~N}$ label in the $\mathrm{NH}_{4}{ }^{+}$pool would have become diluted. Although further transfer of ${ }^{15} \mathrm{~N}$ from $\mathrm{NH}_{4}{ }^{+}$to $\mathrm{NO}_{3}{ }^{-}$ could not be detected after $6 \mathrm{~h}$ (Fig. 3a), nitrifier growth and likely nitrification of regenerated $\mathrm{NH}_{4}{ }^{+}$still continued for at least several hours at the same rate (Fig. 3c). Highest nitrification rates were recorded with both methods in the fresh water region of the estuary and decreased toward the North Sea, similar to the observed pattern of $\mathrm{NH}_{4}{ }^{+}$ concentrations (Figs. $2 \& 4$ ). With the ${ }^{15} \mathrm{~N}$ method, nitrification rates ranged from $700 \mathrm{nM} \mathrm{N} \mathrm{h}{ }^{-1}$ in October to $150 \mathrm{nM} \mathrm{N} \mathrm{h}^{-1}$ in April in fresh water, and from $20 \mathrm{nM} \mathrm{N} \mathrm{h}^{-1}$ to not detectable in marine water. With the ${ }^{14} \mathrm{C}$ method, rates at Stn 0 ranged from $150 \mathrm{nM} \mathrm{C} \mathrm{h}^{-1}$ in October to not detectable in January. Nitrification rates decreased toward Stn 28 where values from $1 \mathrm{nM} \mathrm{C} \mathrm{h}^{-1}$ in January to $10 \mathrm{nM} \mathrm{C} \mathrm{h}^{-1}$ in October were measured (Table 1).

In January, high rates were measured with the ${ }^{15} \mathrm{~N}$ method and not detectable or very low rates with the ${ }^{14} \mathrm{C}$ method (Fig. 4, Table 1). In April, the ${ }^{15} \mathrm{~N}$ method also showed relatively high activity compared to growth when measured using the ${ }^{14} \mathrm{C}$ method at Stn 8. This corresponded to an increase in SPM content at this station during this season (Fig. 2). The error was larger when a fitted curve was used to calculate nitrification rates (Fig. 4 \& Table 1). This observation should be taken into account when interpreting results.

Table 1. Comparison of nitrification rates measured with ${ }^{15} \mathrm{~N}$ and ${ }^{14} \mathrm{C}$ methods (see 'Materials and methods') at 5 salinities during 4 seasons. Curve (C): nitrification rate for ${ }^{15} \mathrm{~N}$ method calculated using fitted curve, Line (L): nitrification rate for ${ }^{15} \mathrm{~N}$ method calculated using fitted line, nd: not detectable, errors are SE calculated from fitted parameters

\begin{tabular}{|c|c|c|c|c|c|}
\hline Salinity & Month & $\begin{array}{c}{ }^{15} \mathrm{~N}^{-1} \\
\left(\mathrm{nM} \mathrm{N} \mathrm{h}^{-1}\right)\end{array}$ & $\begin{array}{c}{ }^{14} \mathrm{C} \\
\left(\mathrm{nM} \mathrm{C} \mathrm{h}^{-1}\right)\end{array}$ & $\begin{array}{l}\mathrm{N}: \mathrm{C} \\
\text { ratio }\end{array}$ & $\begin{array}{c}\text { Calculation } \\
\text { method }\end{array}$ \\
\hline 0 & $\begin{array}{l}\text { Jan } \\
\text { Apr } \\
\text { Jul } \\
\text { Oct }\end{array}$ & $\begin{array}{l}395.2 \pm 251.0 \\
146.6 \pm 5.0 \\
620.9 \pm 106.8 \\
701.5 \pm 22.1\end{array}$ & $\begin{array}{c}\text { nd } \\
44.1 \pm 3.0 \\
114.0 \pm 0.3 \\
150.0 \pm 27.0\end{array}$ & $\begin{array}{c}\text { nd } \\
3.3 \pm 0.3 \\
5.4 \pm 0.9 \\
4.7 \pm 0.9\end{array}$ & $\begin{array}{l}\text { C } \\
L \\
C \\
L\end{array}$ \\
\hline 2 & $\begin{array}{l}\text { Jan } \\
\text { Apr } \\
\text { Jul } \\
\text { Oct }\end{array}$ & $\begin{aligned} 437.3 & \pm 105.2 \\
97.2 & \pm 10.4 \\
124.3 & \pm 1.9 \\
696.8 & \pm 68.7\end{aligned}$ & $\begin{aligned} 8.9 & \pm 1.2 \\
14.6 & \pm 2.5 \\
55.5 & \pm 6.3 \\
117.8 & \pm 14.2\end{aligned}$ & $\begin{array}{c}49.2 \pm 13.5 \\
6.7 \pm 1.4 \\
2.2 \pm 0.3 \\
5.9 \pm 0.9\end{array}$ & $\begin{array}{l}\mathrm{L} \\
\mathrm{L} \\
\mathrm{L} \\
\mathrm{L}\end{array}$ \\
\hline 8 & $\begin{array}{l}\text { Jan } \\
\text { Apr } \\
\text { Jul } \\
\text { Oct }\end{array}$ & $\begin{aligned} 59.5 & \pm 18.8 \\
116.7 & \pm 14.0 \\
254.0 & \pm 125.0 \\
96.5 & \pm 10.5\end{aligned}$ & $\begin{array}{c}5.5 \pm 0.1 \\
1.9 \pm 2.5 \\
26.5 \pm 17.3 \\
29.8 \pm 1.0\end{array}$ & $\begin{array}{c}10.8 \pm 3.4 \\
60.2 \pm 77.2 \\
9.6 \pm 7.8 \\
3.2 \pm 0.4\end{array}$ & $\begin{array}{l}C \\
L \\
C \\
L\end{array}$ \\
\hline 18 & $\begin{array}{l}\text { Jan } \\
\text { Apr } \\
\text { Jul } \\
\text { Oct }\end{array}$ & $\begin{array}{c}23.5 \pm 9.3 \\
\text { nd } \\
6.9 \pm 1.8 \\
\text { nd }\end{array}$ & $\begin{array}{l}1.7 \pm 0.2 \\
\text { nd } \\
\text { nd } \\
2.0 \pm 0.6\end{array}$ & $\begin{array}{c}13.7 \pm 5.8 \\
\text { nd } \\
\text { nd } \\
\text { nd }\end{array}$ & $\begin{array}{l}\mathrm{C} \\
\mathrm{L}\end{array}$ \\
\hline 28 & $\begin{array}{l}\text { Jan } \\
\text { Apr } \\
\text { Jul } \\
\text { Oct }\end{array}$ & $\begin{array}{c}4.0 \pm 1.1 \\
\text { nd } \\
\text { nd } \\
19.7 \pm 0.7\end{array}$ & $\begin{array}{r}0.6 \pm 0.2 \\
2.6 \pm 7.2 \\
2.9 \pm 5.0 \\
11.3 \pm 7.6\end{array}$ & $\begin{array}{c}6.8 \pm 2.7 \\
\text { nd } \\
\text { nd } \\
1.7 \pm 1.2\end{array}$ & L \\
\hline
\end{tabular}




\section{Pilot study}

$\mathrm{NO}_{3}{ }^{-}$produced during the light and dark incubations is shown in Fig. 5a. It appears that nitrification was linear up to $24 \mathrm{~h}$ and is a light sensitive process. $\mathrm{NH}_{4}{ }^{+}$ concentration at the start of the incubation was $102 \mu \mathrm{M}$ and nitrification rates from light and dark incubations were $443 \pm 9$ and $792 \pm 17 \mathrm{nM} \mathrm{N} \mathrm{h}^{-1}$, respectively. Accordingly, $44 \%$ of the nitrification activity was inhibited by the light. Parallel incubations in the dark with the ${ }^{14} \mathrm{C}$ method revealed a rate of $197 \pm 16 \mathrm{nM} \mathrm{C} \mathrm{h}^{-1}$ (Fig. 5b). When we combined ${ }^{14} \mathrm{C}$ and ${ }^{15} \mathrm{~N}$ methods for dark incubations we observed that $4.0 \pm 0.3$ moles of nitrogen were transformed for each mole of carbon fixed.

\section{DISCUSSION}

Given that nitrification plays a pivotal role in estuarine biogeochemistry, it is essential to have a reliable and accurate technique to quantify the actual activity of ammonium and nitrite oxidizing bacteria. This is especially true when the results are to be used to calculate nitrogen budgets. The ${ }^{14} \mathrm{C}$ method (Somville 1978) is probably the most common way to measure nitrification and is based on quantifying presence and growth of nitrifying bacteria (Brion \& Billen 1998). This approach is an excellent way to determine whether nitrifying bacteria are growing, but it can not be used directly as a quantitative measure of nitrification. Nitrification rates obtained from the ${ }^{14} \mathrm{C}$ method (in carbon units) need to be converted into nitrogen units to be relevant in a nitrogen context. This conversion requires knowledge of how much carbon is fixed by the nitrifier community in order to oxidize a known amount of ammonium to nitrate, and was the subject of extensive research during the 1970s and 1980s (Table 2).

Literature values for conversion ratios have often been determined under optimal laboratory growth conditions on pure strains of oxidizing bacteria, e.g. Nitrosomonas or Nitrospira strains for ammonium oxidation and Nitrobacter strains for nitrite oxidation. These studies (Table 2) revealed highly variable results, with $\mathrm{N}: \mathrm{C}$ ratios ranging from 6.0 (Owens 1986) to 18.9 (Helder \& de Vries 1983). It is questionable whether these ratios are applicable in nature where environmental conditions as well as bacterial populations and composition are variable. Factors such as temperature (Bianchi et al. 1997), salinity (Feliatra \& Bianchi 1993), oxygen concentrations (Carlucci \& McNally 1969, Goreau et al. 1980), and substrate availability (Belser 1984) can affect the $\mathrm{N}: \mathrm{C}$ ratio. The assumption that slow-growing nitrifiers (Helder \& de Vries 1983) have a conversion factor similar to nitrifiers under optimal growth conditions, in such a heterogeneous and highly variable system as an estuary, is quite possibly erroneous. Considering that even optimal growing populations have variable $\mathrm{N}$ :C ratios (Table 2), the applicability of a single, constant conversion factor is even more dubious.

Several studies have expressed strong concerns over this issue. For example, one study conducted under optimal growth conditions produced a low N:C ratio, because the bacteria needed little energy for growth under optimal conditions. Therefore, use of this factor provides a minimum estimate of nitrification activity in situ (Owens 1986). The ${ }^{14} \mathrm{C}$ method can be used as a relative index of nitrification, but accurate estimation of the rate of nitrogen oxidation can only be deduced if a constant ratio exists for natural populations of nitrifying bacteria (Billen 1976). As stated by Hall (1982), 'It is unlikely that one ratio could possibly cover a range
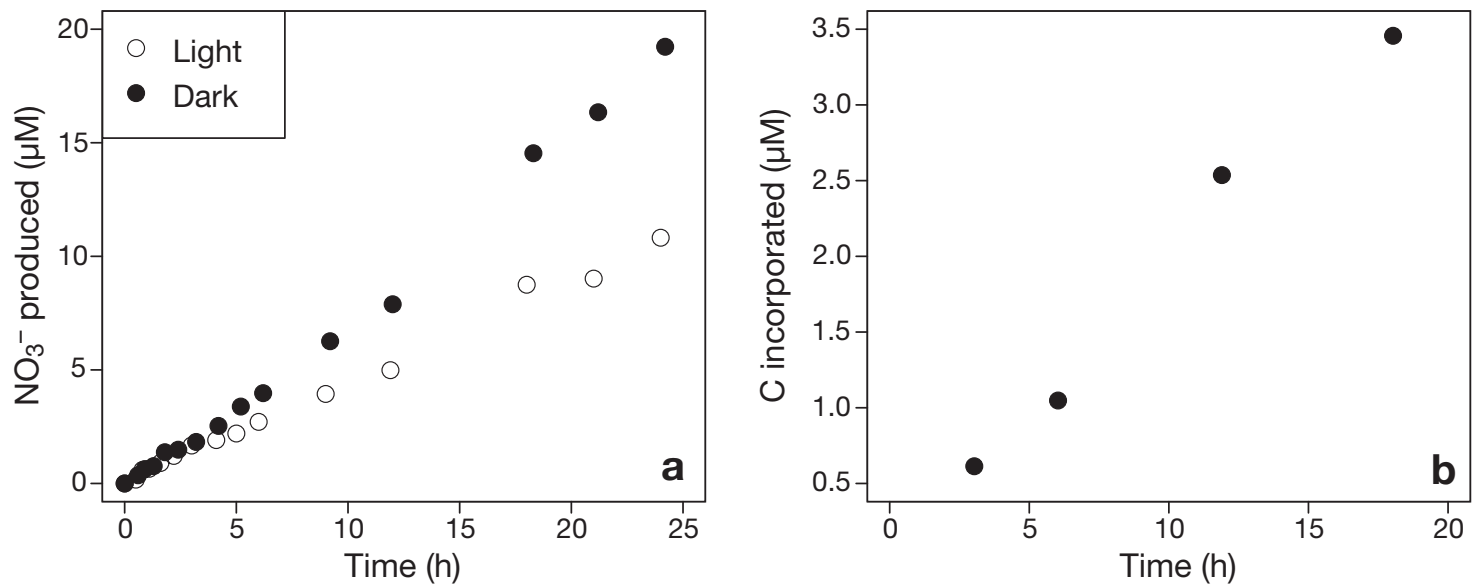

Fig. 5. (a) $\mathrm{NO}_{3}{ }^{-}$produced during light and dark incubations, ${ }^{15} \mathrm{~N}$ method. (b) Carbon incorporated during dark incubations, ${ }^{14} \mathrm{C}$ method. For details of the 2 methods, see 'Materials and methods' 
of environmental conditions and that the absence of reliable data casts doubt on the general applicability of the ${ }^{14} \mathrm{C}$ method as a quantitative measure of nitrification'.

Some attempts have been made to quantify the in situ $\mathrm{N}$ :C ratio through parallel measurements with the ${ }^{14} \mathrm{C}$ method and alternative methods for nitrification (Enoksson 1986, Feliatra \& Bianchi 1993, Dore \& Karl 1996, Bianchi et al. 1997). A ${ }^{15} \mathrm{~N}$ labeling approach similar to the one used in this paper was used by Enoksson (1986), but the addition of labeled $\mathrm{NH}_{4}{ }^{+}$increased the concentration far above ambient concentrations. Consequently, potential rates were obtained and this complicated a direct comparison between methods. Nevertheless, the main conclusion was that the ${ }^{15} \mathrm{~N}$ method and ${ }^{14} \mathrm{C}$ method should be used in parallel in future

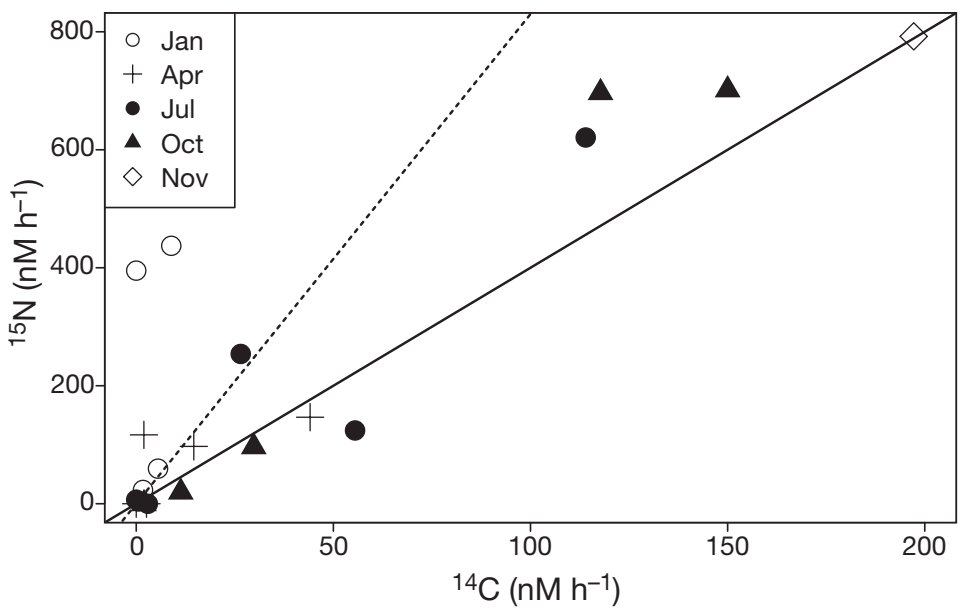

Fig. 6. ${ }^{15} \mathrm{~N}$ method versus ${ }^{14} \mathrm{C}$ method (for details of methods, see 'Materials and methods'). Dashed line: conversion factor 8.3 (Billen 1976); solid line: conversion factor 4.0 (our pilot study), November data: result from pilot study

studies to determine whether the $\mathrm{N}$ : $\mathrm{C}$ ratio is constant. When comparing the ${ }^{14} \mathrm{C}$ method with direct measurements of changes in $\mathrm{NO}_{2}{ }^{-}$and $\mathrm{NO}_{3}{ }^{-}$concentrations in incubated samples, and using an N:C ratio of 8.3 (Billen 1976), Dore \& Karl (1996) found that the 2 independent methods agreed reasonably well in open ocean waters despite exhibiting a high degree of variability. Nitrification has also been assessed with the ${ }^{14} \mathrm{C}$ method and via changes in $\mathrm{NO}_{2}{ }^{-}$ concentrations using specific inhibitors that block the first and the second step of nitrification, respectively (Feliatra \& Bianchi 1993, Bianchi et al. 1997). These studies demonstrated that the $\mathrm{N}$ : C ratio varied with salinity, and decreased from the river to the sea (Feliatra \& Bianchi 1993). In addition, a strong negative correlation between the $\mathrm{N}$ :C ratio (values ranging between 3 and 9) and temperature was observed in the Indian sector of the Southern Ocean, confirming that

the ratio fluctuates with environmental conditions (Bianchi et al. 1997).

Although these studies report variable N:C ratios and concerns about the validity of using 1 fixed ratio in a fluctuating environment, many other studies continue to report nitrification rates in nitrogen units based on the ${ }^{14} \mathrm{C}$ method and converted with a ratio provided by those studies referred to above: e.g. Indrebo et al.(1979), Joye et al. (1999), Brion et al. (2000), and de Bie et al. (2002) used the N:C ratio of Billen (1976); Berounsky \& Nixon (1990, 1993), Iriarte et al. (1997) and Iriarte et al. (1998) used the N:C ratio of Owens (1986); and Jiang \& Bakken (1999a) used the ratio from Belser (1984).

The relationship between nitrifier activity and nitrifier growth observed in our study is shown in Fig. 6. A constant conversion factor imposes a straight line with

Table 2. Comparison of $\mathrm{N}$ : $\mathrm{C}$ ratio values

\begin{tabular}{|c|c|c|c|}
\hline $\mathrm{N}: \mathrm{C}$ & Bacterial community & Studied area & Source \\
\hline 8.3 & Enrichment cultures & North Sea & Billen (1976) \\
\hline 18.9 & $\begin{array}{l}\text { Cultures of pure Nitro- } \\
\text { somonas and Nitrobacter } \\
\text { winogradskyi strains }\end{array}$ & $\begin{array}{l}\text { Ems-Dollard } \\
\text { estuary }\end{array}$ & $\begin{array}{l}\text { Helder \& de Vries } \\
\text { (1983) }\end{array}$ \\
\hline 9.1 & $\begin{array}{l}\text { Cultures of Nitrosomonas } \\
\text { europaea and Nitrospira } \\
\text { sp. strains and Nitrobacter } \\
\text { winogradskyi strains }\end{array}$ & Cultured bacteria & Belser (1984) \\
\hline 6.0 & Enrichment cultures & Tamar estuary & Owens (1986) \\
\hline $8.6-9.8$ & Natural samples & Rhone estuary & $\begin{array}{l}\text { Feliatra \& Bianchi } \\
\text { (1993) }\end{array}$ \\
\hline $2-60$ & Natural samples & Scheldt estuary & Present study \\
\hline
\end{tabular}
a slope corresponding to the quantity of nitrogen transformed per unit carbon fixed. In the Scheldt estuary a conversion factor of 8.3 is often used (Billen 1976), which is shown as a dashed line in Fig. 6. We observed large, systematic deviations from the $\mathrm{N}: \mathrm{C}$ ratio of 8.3 for January and October samples taken in the upper estuary (Fig. 6). Rates measured in January showed high nitrification activity and no or very low growth. In January, the water temperature was $4{ }^{\circ} \mathrm{C}$ and a high $\mathrm{N}$ : C ratio agreed with the strong negative correlation between $\mathrm{N}: \mathrm{C}$ ratio and temperature observed by Bianchi et al. (1997). Temperature decreases have been shown to induce bacteria to increase their sub- 


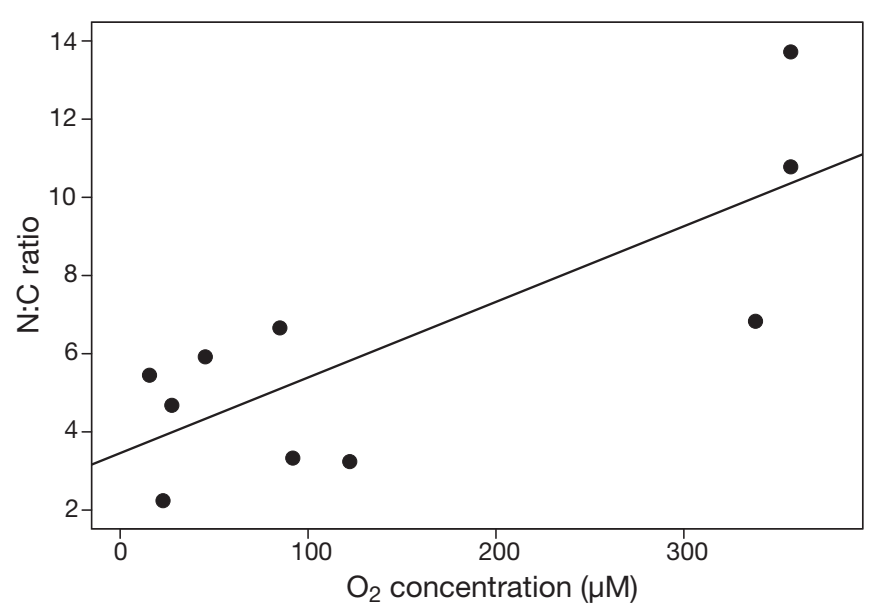

Fig. 7. N:C ratio $<25$ and relative error $<50 \%$ versus $\mathrm{O}_{2}$ concentrations

strate requirement for optimal growth (Wiebe et al. 1992). Accordingly, it may very well be that $\mathrm{N}$ : C ratios of nitrifying communities are seasonally variable in temperate systems. Nitrification can efficiently proceed at low temperatures (even $<0^{\circ} \mathrm{C}$ ) despite the general impression that nitrifiers are inactive at temperatures below 4 to $5{ }^{\circ} \mathrm{C}$ (Collos et al. 1988). High activity without growth might also be due to heterotrophic nitrification, which can constitute a significant fraction of ammonium oxidation under favorable conditions (Zhao et al. 1999). This process would not be detected using the ${ }^{14} \mathrm{C}$ method. A number of common denitrifying bacteria have the ability to carry out heterotrophic nitrification (Castignetti \& Hollocher 1984). Heterotrophic nitrifiers occur among algae, fungi and bacteria and, in comparison to autotrophic nitrifiers, rates of heterotrophic nitrification are low, and occur preferentially under conditions not favorable for autotrophic nitrification (Schmidt et al. 2003). Low water temperatures in January could constitute such a condition. Complete heterotrophic growth has been demonstrated for both Nitrosomonas spp. and Nitrobacter spp. (Hall [1982] and references therein).

In contrast, October rates based on the ${ }^{14} \mathrm{C}$ method were higher than would be predicted from an N:C ratio of 8.3. Our pilot experiment with tidal freshwater was conducted in November 2002 and produced an N:C ratio of 4.0 (solid line, Fig. 6), and October data from 2003 appeared to follow this trend. This result implies that bacteria grow faster during these periods than the energy from nitrification at $\mathrm{N}$ :C ratio of 8.3 would allow. There are several possible explanations for this: (1) bacteria may use an additional energy source or stored energy reserves, (2) community composition of ammonium-oxidizing bacteria in the estuary may vary over time and/or space, and these different communi- ties may have variable optimal $\mathrm{N}: \mathrm{C}$ ratios; metabolic activity and growth rates can differ among cultures (Jiang \& Bakken 1999b) and thus also among different communities, (3) our N:C ratios may have been biased towards low values because of our neglect of ammonium regeneration that caused dilution of ${ }^{15} \mathrm{~N}$, and (4) low $\mathrm{N}$ : C ratios coincided with low oxygen concentrations i.e. $<100 \mu \mathrm{M}$. Higher carbon assimilation per unit nitrogen oxidized at low oxygen concentrations has been observed in several studies (Carlucci \& McNally 1969, Goreau et al. 1980). Our results were consistent with these findings, which demonstrated a significant $\left(p=0.007, R^{2}=0.64\right)$ positive correlation between $\mathrm{N}: \mathrm{C}$ ratio and oxygen concentration (Fig. 7).

Based on our results and previously published studies, we propose that a clear distinction should be made between nitrification activity expressed in units of nitrogen and nitrifier growth expressed in units of carbon. It is only under optimal steady-state conditions, such as in the open ocean or in a lake with long residence time, that a uniform $\mathrm{N}$ : $\mathrm{C}$ ratio is to be expected. Accordingly, we propose that the ${ }^{15} \mathrm{~N}$ method is preferable when nitrifier activity is of interest, while the less costly and less labor intensive ${ }^{14} \mathrm{C}$ method provides a good measure of the growth of chemoautotrophic nitrifying bacteria. In addition to providing a direct measure of nitrifying activity in nitrogen units, the ${ }^{15} \mathrm{~N}$ method has 2 other advantages over the ${ }^{14} \mathrm{C}$ method: (1) the ${ }^{15} \mathrm{~N}$ method is independent of specific inhibitors, and (2) it enables light dependent studies of nitrification. Use of specific inhibitors has been questioned because these may not be $100 \%$ selective, i.e. they may inhibit other processes as well, or because they may not completely block all nitrifying activity (Oremland \& Capone 1988). Not all natural communities of nitrifying bacteria are affected to the same extent by a given inhibitor, and responses to inhibitor concentration may vary among communities (de Bie et al. 2002). Moreover, several inhibitors are not soluble in water and require organic solvents for application, which may affect nitrification rates. One drawback of the ${ }^{15} \mathrm{~N}$ method is that in waters with very low ambient $\mathrm{NH}_{4}{ }^{+}$concentrations, the rates measured will be potential rather than actual in situ nitrification rates. We observed that light inhibited more than $40 \%$ of nitrifying activity and, depending on the system studied, it might be highly relevant to measure light dependence. Earlier studies demonstrated an important relationship between nitrification rate and light intensity (Ward 2005). In cultures of both oceanic and estuarine isolates, $\mathrm{NH}_{4}{ }^{+}$oxidizers in oceanic communities were inhibited by light to a much greater extent than estuarine isolates (Horrigan \& Springer 1990). This result was attributed to high $\mathrm{NH}_{4}{ }^{+}$concentrations and high nitrification rates in estuaries. Our 
light inhibition of $44 \%$ agreed with the findings of Horrigan \& Springer (1990) for 1 of 3 estuarine isolates studied.

\section{CONCLUSIONS}

The present study came to the following conclusions: (1) A comparison between the ${ }^{14} \mathrm{C}$ method and ${ }^{15} \mathrm{~N}$ method for nitrification revealed that growth and activity can be uncoupled and consequently that $\mathrm{N}$ :C ratios can vary (from 2 to 60 in our study); (2) Oxygen concentration and temperature govern $\mathrm{N}$ :C ratios; (3) It is preferential to use ${ }^{15} \mathrm{~N}$ techniques over the ${ }^{14} \mathrm{C}$ method to measure actual nitrification rates; (4) Nitrification is a light sensitive process: $44 \%$ of nitrifying activity was observed to be inhibited by light in this nitrogen-rich, turbid estuary.

Acknowledgements. We thank D. van der Wal and RIKZ Middelburg for providing the template for Fig. 1, P. van Breugel, M. Houtekamer, C. Kleppe-van Zetten, Y. van der Maas, J. Nieuwenhuize and J. Sinke for analytical support, and NIOO PhD students for valuable feedback on the manuscript. We also thank 3 anonymous reviewers for constructive feedback. This study was supported by Flemish-Dutch cooperation funds for Sea Research (NWO 832.11.002 and 832.11.007). This is NIOO-KNAW (Netherlands Institute of Ecology) publication number 3674.

\section{LITERATURE CITED}

Baeyens W, van Eck B, Lambert C, Wollast R, Goeyens L (1998) General description of the Scheldt estuary. Hydrobiologia 366:1-14

Belser LW (1984) Bicarbonate uptake by nitrifiers: effects of growth rate, $\mathrm{pH}$, substrate concentration, and metabolic inhibitors. Appl Environ Microbiol 48:1100-1104

Berounsky VM, Nixon SW (1990) Temperature and the annual cycle of nitrification in waters of Narragansett Bay. Limnol Oceanogr 35:1610-1617

Berounsky VM, Nixon SW (1993) Rates of nitrification along an estuarine gradient in Narragansett Bay. Estuaries 16: 718-730

Bianchi M, Feliatra F, Treguer P, Vincendeau MA, Morvan J (1997) Nitrification rates, ammonium and nitrate distribution in upper layers of the water column and in sediments of the Indian sector of the Southern Ocean. Deep-Sea Res Part II 44:1017-1032

Billen G (1976) Evaluation of nitrifying activity in sediments by dark ${ }^{14} \mathrm{C}$-bicarbonate incorporation. Water Res 10: 51-57

Bodelier PLE, Libochant JA, Blom C, Laanbroek HJ (1996) Dynamics of nitrification and denitrification in root-oxygenated sediments and adaptation of ammonia-oxidizing bacteria to low-oxygen or anoxic habitats. Appl Environ Microbiol 62:4100-4107

Bollmann A, Laanbroek HJ (2002) Influence of oxygen partial pressure and salinity on the community composition of ammonia-oxidizing bacteria in the Schelde estuary. Aquat Microb Ecol 28:239-247
Bollmann A, Bar-Gilissen MJ, Laanbroek HJ (2002) Growth at low ammonium concentrations and starvation response as potential factors involved in niche differentiation among ammonia-oxidizing bacteria. Appl Environ Microbiol 68: 4751-4757

Brion N, Billen G (1998) A reassessment of the $\mathrm{H}^{14} \mathrm{CO}_{3}{ }^{-}$incorporation method for measuring autotrophic nitrification and its use to estimate the biomass of nitrifying bacteria. Rev Sci Eau 11:283-302

Brion N, Billen G (2000) Wastewater as a source of nitrifying bacteria in river systems: the case of the River Seine downstream from Paris. Water Res 34:3213-3221

Brion N, Billen G, Guzennec L, Ficht A (2000) Distribution of nitrifying activity in the Seine river (France) from Paris to the estuary. Estuaries 23:669-682

Caffrey JM, Harrington N, Solem I, Ward BB (2003) Biogeochemical processes in a small California estuary. 2. Nitrification activity, community structure and role in nitrogen budgets. Mar Ecol Prog Ser 248:27-40

Carlucci AF, McNally PM (1969) Nitrification by marine bacteria in low concentrations of substrate and oxygen. Limnol Oceanogr 14:736-739

Castignetti D, Hollocher TC (1984) Heterotrophic nitrification among denitrifiers. Appl Environ Microbiol 47:620-623

Collos Y, Linley EAS, Frikha MG, Ravail B (1988) Phytoplankton death and nitrification at low-temperatures. Estuar Coast Shelf Sci 27:341-347

de Bie MJM, Speksnijder A, Kowalchuk GA, Schuurman T, Zwart G, Stephen JR, Diekmann OE, Laanbroek HJ (2001) Shifts in the dominant populations of ammonia-oxidizing beta-subclass proteobacteria along the eutrophic Schelde estuary. Aquat Microb Ecol 23:225-236

de Bie MJM, Starink M, Boschker HTS, Peene JJ, Laanbroek HJ (2002) Nitrification in the Schelde estuary: methodological aspects and factors influencing its activity. FEMS Microbiol Ecol 42:99-107

de Wilde HPJ, de Bie MJM (2000) Nitrous oxide in the Schelde estuary: production by nitrification and emission to the atmosphere. Mar Chem 69:203-216

Dore J, Karl D (1996) Nitrification in the euphotic zone as a source for nitrite, nitrate, and nitrous oxide at Station ALOHA. Limnol Oceanogr 41:1619-1628

Dugdale RC, Goering JJ (1967) Uptake of new and regenerated forms of nitrogen in primary productivity. Limnol Oceanogr 12:196-206

Enoksson V (1986) Nitrification rates in the Baltic Sea: comparison of three isotope techniques. Appl Environ Microbiol 51:244-250

Feliatra F, Bianchi M (1993) Rates of nitrification and carbon uptake in the Rhone River plume (northwestern Mediterranean Sea). Microb Ecol 26:21-28

Garnier J, Servais P, Billen G, Akopian M, Brion N (2001) Lower Seine river and estuary (France) carbon and oxygen budgets during low flow. Estuaries 24:964-976

Gazeau F, Gattuso JP, Middelburg JJ, Brion N, Schiettecatte LS, Frankignoulle M, Borges AV (2005) Planktonic and whole system metabolism in a nutrient-rich estuary (the Scheldt estuary). Estuaries 28(6):868-883

Goreau TJ, Kaplan WA, Wofsy SC, McElroy MB, Valois FW, Watson SW (1980) Production of $\mathrm{NO}_{2}{ }^{-}$and $\mathrm{N}_{2} \mathrm{O}$ by nitrifying bacteria at reduced concentrations of oxygen. Appl Environ Microbiol 40:526-532

Hall GH (1982) Apparent and measured rates of nitrification in the hypolimnion of a mesotrophic lake. Appl Environ Microbiol 43:542-547

Heip CHR (1988) Biota and abiotic environment in the Westerschelde estuary. Hydrobiol Bull 22:31-34 
Helder W, de Vries RTP (1983) Estuarine nitrite maxima and nitrifying bacteria (EMS-Dollard estuary). Neth J Sea Res 17:1-18

Holmes RM, McClelland JW, Sigman DM, Fry B, Peterson BJ (1998) Measuring ${ }^{15} \mathrm{~N}-\mathrm{NH}_{4}{ }^{+}$in marine, estuarine and fresh waters: an adaptation of the ammonia diffusion method for samples with low ammonium concentrations. Mar Chem 60:235-243

Horrigan SG, Springer AL (1990) Oceanic and estuarine ammonium oxidation-effects of light. Limnol Oceanogr 35:479-482

Indrebo G, Pengerud B, Dundas I (1979) Microbial activities in a permanently stratified estuary. II. Microbial activities at the oxic-anoxic interface. Mar Biol 51:305-309

Iriarte A, deMadariaga I, DiezGaragarza F, Revilla M, Orive E (1997) Primary plankton production, respiration and nitrification in a shallow temperate estuary during summer. J Exp Mar Biol Ecol 208:127-151

Iriarte A, de la Sota A, Orive E (1998) Seasonal variation of nitrification along a salinity gradient in an urban estuary. Hydrobiologia 362:115-126

Jiang QQ, Bakken LR (1999a) Nitrous oxide production and methane oxidation by different ammonia-oxidizing bacteria. Appl Environ Microbiol 65:2679-2684

Jiang QQ, Bakken LR (1999b) Comparison of Nitrosospira strains isolated from terrestrial environments. FEMS Microbiol Ecol 30:171-186

Joye SB, Connell TL, Miller LG, Oremland RS, Jellison RS (1999) Oxidation of ammonia and methane in an alkaline, saline lake. Limnol Oceanogr 44:178-188

Middelburg JJ, Nieuwenhuize J (2001) Nitrogen isotope tracing of dissolved inorganic nitrogen behaviour in tidal estuaries. Estuar Coast Shelf Sci 53:385-391

Nieuwenhuize J, Maas YEM, Middelburg JJ (1994) Rapid analysis of organic-carbon and nitrogen in particulate

Editorial responsibility: Bess B. Ward,

Princeton, New Jersey, USA materials. Mar Chem 45:217-224

Oremland RS, Capone DG (1988) Use of specific inhibitors in biogeochemistry and microbial ecology. Adv Microb Ecol 10:285-383

Owens NJP (1986) Estuarine nitrification: a naturally occurring fluidized bed reaction? Estuar Coast Shelf Sci 22: $31-44$

Schmidt I, Sliekers O, Schmid M, Bock E, Fuerst J, Kuenen JG, Jetten MSM, Strous M (2003) New concepts of microbial treatment processes for the nitrogen removal in wastewater. FEMS Microbiol Rev 27:481-492

Sigman DM, Altabet MA, Michener R, McCorkle DC, Fry B, Holmes RM (1997) Natural abundance-level measurement of the nitrogen isotopic composition of oceanic nitrate: an adaptation of the ammonia diffusion method. Mar Chem 57:227-242

Soetaert K, Herman PMJ (1995) Carbon flows in the Westerschelde Estuary (the Netherlands) evaluated by means of an ecosystem model (Moses). Hydrobiologia 311:247-266

Soetaert K, Middelburg JJ, Heip C, Meire P, Van Damme S, Maris T (2005) Long-term change in dissolved inorganic nutrients in the heterotrophic Scheldt estuary (Belgium, the Netherlands). Limnol Oceanogr 51(1, Part 2):409-423

Somville M (1978) A method for the measurement of nitrification rates in water. Water Res 12:843-848

Ward BB (2005) Temporal variability in nitrification rates and related biogeochemical factors in Monterey Bay, USA. Mar Ecol Prog Ser 292:97-109

Wiebe WJ, Sheldon WM, Pomeroy LR (1992) Bacterial-growth in the cold - evidence for an enhanced substrate requirement. Appl Environ Microbiol 58:359-364

Zhao HW, Mavinic DS, Oldham WK, Koch FA (1999) Controlling factors for simultaneous nitrification and denitrification in a two-stage intermittent aeration process treating domestic sewage. Water Res 33:961-970

Submitted: April 14, 2005; Accepted: September 28, 2005

Proofs received from author(s): February 6, 2006 